\title{
定電流法による $\mathrm{NaCl}-\mathrm{KCl}$ (当モル) 融解塩中での $\mathrm{Zr}^{2+}$ イオンの還元について
}

\author{
Galvanostatic determination of Kinetic Parameters of Reaction \\ "Zrr ${ }^{2+}+2 e \rightarrow \mathrm{Zr}$ " in NaCl-KCl $(e q \cdot \mathrm{mol})$ Melts
}

\section{1 緒 言}

融解塩を用いて金属ジルコニウムの電解精製の基䃈と してすでに本誌に扔いて $\mathrm{NaCl}-\mathrm{KCl}$ 融解塩中における $\mathrm{Zr}^{2+}, \mathrm{Zr}^{4+}$ イオンの应散係数 ${ }^{1)}$ 拉よび二塩化ジルコニウ ムの平衡電位 ${ }^{2}$ について明らかにした。 その際 $\mathrm{NaCl}$ $\mathrm{KCl}$ 融解塩中には $700^{\circ} \mathrm{C} \sim 900^{\circ} \mathrm{C}$ において金属ジルコ ニウムと平衡するジルコニウム塩はほとんど二塩化物で あり，金属ジルコニウムの電解析出の主反応はほとんど $\mathrm{Zr}^{2+}+2 e \rightarrow \mathrm{Zr}$ と考えられるので本報に执いては定電流 法によってこの電極反応の動力学的パラメーター，すな わち速度定数 $k_{f}$ (正方向), $k_{b}$ (逆方向)， $k_{s}$ (標準),

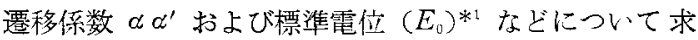
めた。

\section{2 実験}

\section{1 実験方法}

電極上での反応は,

$$
0+n e \rightarrow R
$$

であるとし，還元体 $(R)$ 金属の活量は一定と考えられ るように $R$ と固溶しない電極タングステンを用いた。 また物質の移動過程が平面昖散で行なわれる上らな低濃 度を選んだ。このような場合フィックの拉散第二法則が 成立する。すなわち，

$$
\partial C_{0}(x \cdot t) / \partial t=D_{0} \cdot \partial^{2} C_{0}(x \cdot t) / \partial x^{2}
$$

ここで $x$ は電極面からの距離, $C_{0}$ は酸化体の濃度, $D_{0}$ は酸化体の扡散係数を示寸. 今初期条件として電解前に は酸化体のみが存在する.すなわち, $C_{0}(x \cdot 0)=C_{0}, C_{R}$ $(x \cdot 0)=0$, 境界条件としては電解中電流密度 $\left(i_{0}\right)$ が一 定 (定電流) に規正されるから，

$$
\left\{\partial C_{0}(x \cdot t) / \partial t\right\}_{x=0}=i_{0} / n F D_{0}=\lambda
$$

さらに電極表面での酸化体と還元体の流速の和はゼロで あるような短時間を選べば電極面に执いて，

$$
D_{0}\left\{\partial C_{0}(x \cdot t) / \partial x\right\}_{x=0}+D_{R}\left\{\partial C_{R}(x \cdot t) / \partial x\right\}_{x=0}=0
$$

がなりたちうる、ここで $D_{R}$ 㶎元体の拉散係数を示 才. 最後に, $x \rightarrow \infty$ で $C_{0}(x \cdot t)=C_{0}, C_{R}(x \cdot t)=0$.

上述の初期拉よび境界值問題注多〈の研究者 ${ }^{3}$ によ。

* 名古屋大学工学部（愛知県名古屋市干種区不老町）

*1 無限希积基算仁上万標準電位
坂倉 富 良*, 桐原朝夫*

Tomiyoshi Sakakura, Tomoö Kirihara

て解かれ，電極の表面濃度は時間の関数として次式で示 される。

$$
\begin{aligned}
C_{0}(0 \cdot t) & =C_{0}-2 \lambda \cdot\left(D_{0} t / \pi\right)^{3 / 2} \\
C_{R}(0 \cdot t) & =2 \lambda D_{0}\left(t / D_{R} \pi\right)^{1 / 2}
\end{aligned}
$$

ここで $C_{0}(0 \cdot t), C_{R}(0 \cdot t)$ はそれぞれ酸化体，還元体の 表面濃度， $C_{0}$ 酒酸化体の母液濃度を示す，したがって (2),(3) 式より電流密度は 電流 $\times(\text { 時間 })^{1 / 2}$ の関数とし て次式で示される.

$$
\begin{aligned}
i_{0} & =n F\left[k_{f} C_{0}(0 \cdot t)-k_{b} C_{R}(0 \cdot t)\right] \\
& =n F k_{f} C_{0}-\left\{2 / \sqrt{\pi} \cdot\left(k f / \sqrt{D_{0}}+k_{b} / \sqrt{D_{R}}\right)\right\} \cdot i_{0} t^{1 / 2}
\end{aligned}
$$

ここで $k_{f}, k_{b}$ はそれぞれ電位 $E$ での正方向，逆方向 の速度定数である.（4）式は $i_{0}-i_{0} t^{1 / 2}$ の関倸は直線を 示し $i_{0} t^{1 / 2}=0$ においては, 電荷移動過程の電流密度す なわち初期電流密度 $n F k_{f} C_{0}$ が求まり，乙れより $k_{f}$ を 求めうる. 一方この直線のこう配は $-2 / \sqrt{\pi}\left(k_{f} \sqrt{D_{0}}+\right.$ $\left.k_{b} / \sqrt{D_{R}}\right)$ を示し， $D_{0} D_{R}$ が既知であれば $k_{b}$ を求める ことが可能である. また $k_{f}, k_{b}$ は次式で示される.

$$
\begin{gathered}
k_{f}=k_{f}{ }^{0} \exp (-\alpha n F E / R T) \\
k_{b}=k_{b}{ }^{0} \exp \left(\alpha^{\prime} n F E / R T\right)
\end{gathered}
$$

ここで $k_{f}{ }^{0}, k_{b}{ }^{0}$ はそれぞれ $E=0$ (塩素基準電位) での 正方向，逆方向の速度定数を示し， $\alpha ＼alpha^{\prime}$ はそれぞれ正 方向, 逆方向の遷移係数で一般に $\alpha+\alpha^{\prime}=1$ と考えられ る。

(5),(6) 式の関係より $a, \alpha^{\prime}, k_{f^{0}}, k_{b}{ }^{0}$ が算出可能であ る、もし本実娩のごとく $D_{R}$ が不明の場合でも，この系 の平衡電位を測定すれば $k_{b}$ を求めることができる。す なわち平衡電位においては，

$$
k_{f E e} C_{0}=k_{b E e} C_{R}
$$

(7) 式にて $C_{R}$ は純物質 $(\mathrm{mol} / \mathrm{c} . \mathrm{c})$ を考光, $k_{f E e}, k_{b E e}$ はともに平衡電位に抢ける正逆方向の速度定数を示す。 (7) 式により $k_{b E e}$ が求まり $D_{R}$ もあわせて求めうる。 平衡電位においても（6）式注成立する伸完，

$$
k_{b E_{e}}=k_{b}{ }^{0} \exp \left(\alpha^{\prime} n F E e / R T\right)
$$

他方 (4) 式に执いて $k_{b} \sqrt{D_{R}}$ が求まる㠴え(6) 式の両 辺を $D_{R}^{1 / 2}$ で除した式すなうち，

$$
k_{b} / \sqrt{D_{R}}=k_{b}{ }^{\circ} / \sqrt{D_{R}} \exp \left(\alpha^{\prime} n F E / R T\right)
$$

より $\log \left(k_{b} / \sqrt{D_{R}}\right)-E$ の関係をプロットすれば，その こう配は $\alpha^{\prime} n F / R T$ を示し $\alpha^{\prime}$ が求まる。この $\alpha^{\prime}$ を求 
めれ代 (8) 式より $k_{b}{ }^{0}$ が求まり，各電位における $k_{b}$ が 求动らる。虫た，

$$
\begin{aligned}
k_{s} & =k_{f}{ }^{0} C_{0 \infty} \exp \left(-\alpha n F E^{0} / R T\right) \\
& =k_{b}{ }^{0} C_{R} \text { pure state } \exp \left(\alpha^{\prime} n F E^{0} / R T\right)
\end{aligned}
$$

の関倸より無陙希橎基準の標準電位 $E^{0} お$ おび標準速度 定数 $k_{s}$ を求めうる. ここで $C_{00}$ は無限希积を基準と した仦想的な純物質の状態の濃度で溶液の比重が既知で 离れば求为方れる。 $C_{R}$ pure state は還元体金属の濃度 ( $\mathrm{mol} / \mathrm{c} . \mathrm{c})$ である。なお本奉験において後述するごとく $\alpha+\alpha^{\prime} \neq 1$ となり $\alpha=1-\alpha=\alpha^{\prime}$ と考えた場合と $\alpha, \alpha^{\prime}$ の 実駼值 $\left(\alpha+\alpha^{\prime} \neq 1\right)$ を气のまま用いて速度定数, 標準 電位を算出した場合とについて述べた。

\section{2 測定方法および装置}

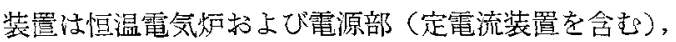
気体精製装置および過電圧時間測定装置からなり，その 詳細については前報》,23 と同じで略した. 図 1 亿は定電 流装置，測定ソウおよび過電圧時間測定装置について概
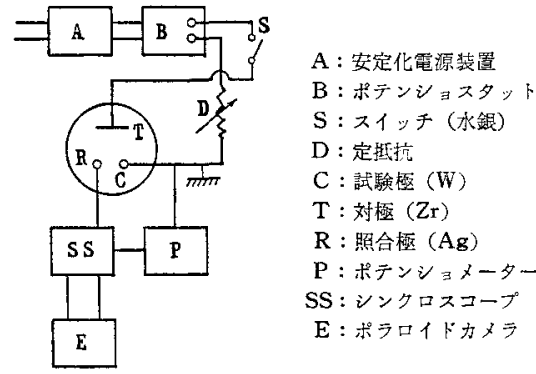

図 1 測定装置の概要

要的に示してある. 定電流発生装置としては, 定電流発 生用のパルス発生器々定電流発生用のデイケード抵抗器 よりなり，パルス発生器はトリガーパルスにより駆動さ れパルス幅は $10 \mathrm{~ms}$ 以上任意であり，立ち上り時間 2 $\mathrm{m} \mu \mathrm{sec}$, 出力容量 $300 \mathrm{~V}, 300 \mathrm{~mA}$ である. またデイケ 一ド型抵抗器は定電流発生用の抵抗 器 で $1 \mathrm{k} \Omega \sim 31.11$ $\mathrm{M} \Omega, 5$ ダイヤル切替型で $300 \mathrm{~V}, 300 \mathrm{~mA}$ の電源に耐 えるようにしてあり，その精度は $\pm 1 \%$ である。

本実験に おいて抵抗值 $900 \mathrm{k} \Omega \sim 3 \mathrm{M} \Omega$, 電流 0.1 $\sim 0.4 \mathrm{~mA}$ の簖囲に拈いて使用した，過電圧時閒測定回 路にはポテンショメーター（P）によって電位軸のゼロ 点をずらして電荷移動過程から物質移動過程に移行する 部分の電位がシンクロスコープ $(\mathrm{S} \cdot \mathrm{S})$ のブラウン管面 の中央にくるようにして測定を行なった.

測定ソウの配置を図 2 に示す. 浴塩 $(\mathrm{NaCl}-\mathrm{KCl}$ 当そ ル）, 金属ジルニニウム，および塩化銀電極（塩化銀濃 度 0.06 モル分率）については前報1，2) と全く同じであ $り ，$ 浴温度の調節 $\left( \pm 1^{\circ} \mathrm{C}\right)$ 二塩化ジルコニウムの添加方 法は前報に詳紏に述べた金属ジルコニウムの電解溶出， ジルコニウム還元，水素還元による方法によって浴中に

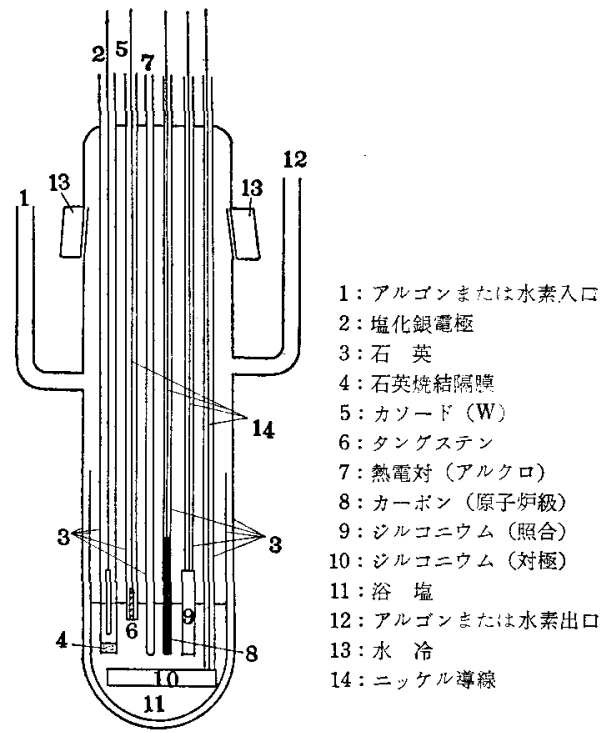

图 2 測 定 ソ ウ

おいて生成させた。測定陰極 (5) はタングステンを石英 に封入して表面を研摩し，その面積を桩大鏡にて正確に 算出した。実験に用いた電極面積は $0.103 \sim 0.231 \mathrm{~cm}^{2}$ で少数点以下 3 けたまで正確に測定できた. 照合電極と しては陽極溶出に用いたものと同純度の金属ジルコニウ ム板を使用した。 また本実験にて各温度における平衡電 位 (二塩化ジルコニウム濃度 $4.33 \times 10^{-4}$ モル分率) は 塩化銀電極を用いて測定し，前報2)の結果を用いて塩素 基準で求めた。

\section{3 実験結果および考察}

\section{1 過電圧時間曲線}

測定した過電圧時間曲線の一例を図 3 に示した. 図 3 は $830^{\circ} \mathrm{C}$, 二塩化ジルコニウム濃度 $4.33 \times 10^{-4}$ モル分 率 $\left(6.54 \times 10^{-6} \mathrm{~mol} / \mathrm{c} . \mathrm{c}\right)$, 電極面積 $0.231 \mathrm{~cm}^{2}$ の結果 を示した。なお抵抗補正についてはJ. O'M. Bockris

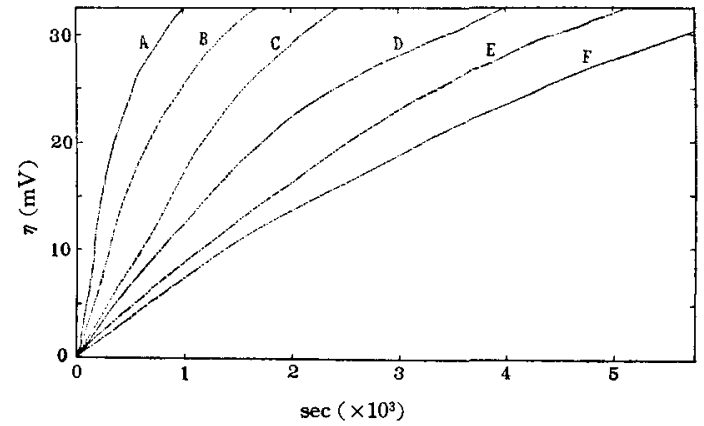

A : $1.300 \mathrm{~mA} / \mathrm{cm}^{2}, D: 0.999 \mathrm{~mA} / \mathrm{cm}^{2}$ B : $1.181 \mathrm{~mA} / \mathrm{cm}^{2}$, E $: 0.928 \mathrm{~mA} / \mathrm{cm}^{2}$

$\mathrm{C}: 1.082 \mathrm{~mA} / \mathrm{cm}^{2}, F: 0.866 \mathrm{~mA} / \mathrm{cm}^{2}$

$C_{\mathrm{ZrCl}_{3}}: 6.54 \times 10^{-6} \mathrm{~mol} / \mathrm{cc}$, 温度 : $830^{\circ} \mathrm{C}$, 電㓙面皘 $: 0.231 \mathrm{~cm}^{2}$ 図 3 電位時間曲線 
ららの行なっている方法で補正を行なった。この過電圧 時間の関倸については P. Delahay ら务が述べているよ う電荷移動過電圧が小さい範囲に扔、て注，次式で示 される。すなるち，

$$
\begin{aligned}
\eta= & -R T / n F\left[1 / i_{0}+2 / n F \sqrt{\pi}\right. \\
& \times\left(1 / \mathrm{C}_{0} \sqrt{D_{0}}+1 / C_{R} \sqrt{D_{R}}\right) \sqrt{t}-R T / n F \\
& \left.\times\left\{1 / n F\left(1 / C_{0} \sqrt{D_{0}}+1 / C_{R} \sqrt{D_{R}}\right)\right\}^{2} C_{d l}\right]
\end{aligned}
$$

ここでク注過電圧, $C_{d l}$ 注電気二重層の微分容量を示 す.上式の第一項议電荷移動，第二項注物質移動，第三 項は䉓気二重層の充電による項である。本実験において 電気二重層の荷電電流の影響が現われるのは，今電気二 重層容量を $110 \mu F^{7}$, 電極表面積在 $2.3 \times 10^{-1} \mathrm{~cm}^{2}$, 液 抵抗を $1 \Omega^{8)}$ とするとき時定数は $2.5 \times 10^{-5}$ 秒となる. この実験にては渦電圧時間の解析がこの時閒領域に大ら ないので電気二重層充電の影響はないものと考えた。乙 かし実験に打いて過電圧 $5 \mathrm{mV}$ 以下については溶融塩中 の不純物の影響，あるいは電極（タングステン）表面状 態の差異などのため，各実験値とも再現性にそしく結果 より除外した，電流密度について注もらろん遷移時間 $(\bar{L})$ が現われる電流密度よりも小さい領域の電流密度を 選定しなくてはならないが，余り低い電流密度を選ぶと 前述の不純物，表面状態の差異に上る影響が現われ，良 好な過電任時間曲線が得られない，本実験においては， 電流密度 0.4 1.4 mA の範囲で行なった。な拉電極表 面積の変化については，いま電流密度を $1.4 \mathrm{~mA}$ ，時間 を $10^{-2}$ 秒として考えると析出金属ジルコニウムの体積 は比重 6.5 と考学ると $2.4 \times 10^{-10} \mathrm{~cm}^{3}$ となり，電極表 面積の变化率は $2 \times 10^{-7} \%$ となり，完全に誤差の範囲と なり電極面積の変化はこの実験にては考慮外となる.

\section{$3.2 i_{0}-i_{0} t^{1 / 2}$ の関係}

3.1 項で述べた $\eta-t$ 曲線から $i_{0}-i_{0} t^{1 / 2}$ の関倸をプロ ットすると図 4 に示すごとき直線が得られる，図法温度 $830^{\circ} \mathrm{C}$,二塩化ジルコニウムの濃度 $6.54 \times 10^{-6} \mathrm{~mol} / \mathrm{c} . \mathrm{c} の$ 場合を示し,過電圧 $10 \mathrm{mV} \sim 30 \mathrm{mV}$ の範围について示し た。この図に执いて電流密度の小さい範围抢よび過電圧 の小なる範囲，または大なる範囲に抢いては直線性はや や悪くなる.お扔の扮のの場合について $i_{0} t^{1 / 2}$ をい゙ロ外そ うして得られる初期電流密度上り電荷移動過程の正方向 の速度定数を求めた.一方この直線のこう配は $-2 / \sqrt{\pi}$ $\left(k_{f} / \sqrt{D_{0}}+k_{b} / \sqrt{D_{R}}\right)$ を示し $D_{0}$ が既知 $^{1)}$ であるから， $k_{b} / \sqrt{D_{R}}$ が求为られる. $k_{f}, k_{b} / \sqrt{D_{R}}$ の過電圧淿よる

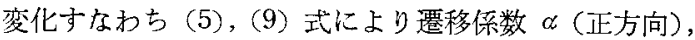
$\alpha^{\prime}$ (逆方向) 在求为た. $720^{\circ} \mathrm{C}, 830^{\circ} \mathrm{C}, 860^{\circ} \mathrm{C}$ の結果を 表 1 3 亿示した.

この表より $\alpha_{\text {mean }}$ の值は $0.35\left(720^{\circ} \mathrm{C}, 830^{\circ} \mathrm{C}\right), 0.38$ $\left(860^{\circ} \mathrm{C}\right) \alpha_{\text {mean }}^{\prime}$ の值性 $0.56\left(720^{\circ} \mathrm{C}\right), 0.58\left(830^{\circ} \mathrm{C}\right), 0.59$ $\left(860^{\circ} \mathrm{C}\right)$ となり $\alpha_{\text {mean }}+\alpha_{\text {mean }}^{\prime}$ の值は $720^{\circ} \mathrm{C}, 830^{\circ} \mathrm{C}$, $860^{\circ} \mathrm{C}$ においてそれぞれ0.91,0.93,0.95 となり1に等

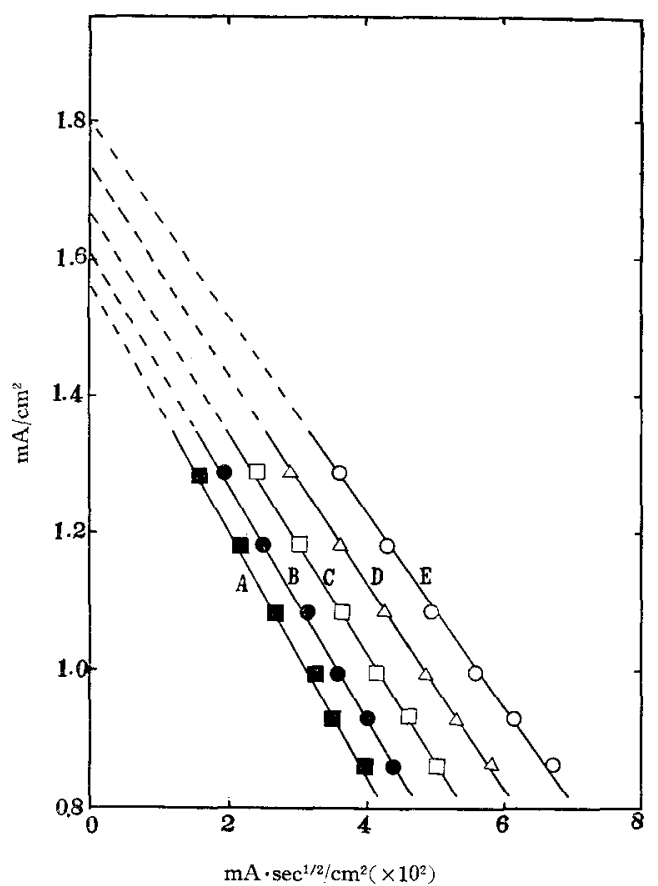

$\mathrm{A}: \eta=10 \mathrm{mV}, \mathrm{B}: \eta=15 \mathrm{mV}, \mathrm{C}: \eta=20 \mathrm{mV}, \mathrm{D}: \eta=25 \mathrm{mV}$, $\mathrm{E}: \eta=30 \mathrm{mV} \quad$ 温度 : $830^{\circ} \mathrm{C}$

図 $4 \mathrm{NaCl}-\mathrm{KCl}$ (当モル) 中での $\mathrm{Zr}^{2+}$ の $i_{0}-i_{0} t^{1 / 2}$ の関係

しくない，今後の課題としてさらに検討する予定です る.

\section{3 標準速度定数 $\left(\boldsymbol{k}_{s}\right)$ および標準電位 $\left(\boldsymbol{E}^{0}\right)$}

表 $1 \mathrm{NaCl}-\mathrm{KCl}$ (当モル) 融解塩中での $\mathrm{Zr}^{2+}$ イホン の遠元反応の速度諭的パラメーター $\left(720^{\circ} \mathrm{C}\right)$

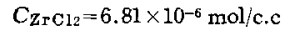

\begin{tabular}{c|c|c|c|c|c}
\hline$\eta(\mathrm{mV})$ & 10 & 15 & 20 & 25 & 30 \\
\hline$i_{0}\left(\mathrm{~mA} / \mathrm{cm}^{2}\right)$ & $1.14_{7}$ & $1.19_{6}$ & $1.24_{8}$ & $1.30_{1}$ & $1.35_{3}$ \\
$k_{f}(\mathrm{~cm} / \mathrm{sec}) \times 10^{3}$ & 0.873 & 0.910 & 0.950 & 0.990 & 1.03 \\
$-2 / \sqrt{\pi} \times$ & 32.4 & 30.5 & 28.3 & 26.9 & 24.7 \\
$\left(k_{f} / \sqrt{D_{0}}+k_{b} / \sqrt{D_{R}}\right)$ & & & & & 0.23 \\
$k_{f} / \sqrt{D_{0}}$ & 0.19 & 0.20 & 0.21 & 0.22 & 0.23 \\
$k_{b} / \sqrt{D_{R}}$ & 28.5 & 26.8 & 25.0 & 23.6 & 21.7 \\
$\alpha$ & $0.34_{7}$ & $0.34_{6}$ & $0.35_{3}$ & $0.35_{3}$ & $0.35_{1}$ \\
$\alpha^{\prime}$ & $0.55_{3}$ & $0.55_{5}$ & $0.56_{7}$ & $0.55_{0}$ & $0.58_{3}$ \\
\hline
\end{tabular}

$D_{0}=2.05 \times 10^{-5} \mathrm{~cm}^{2} / \mathrm{sec}$

表 $2 \mathrm{NaCl}-\mathrm{KCl}$ (当モル) 融解盐中での $\mathrm{Zr}^{2+}$ イオン の還元反応の速度論的パラメーター $\left(830^{\circ} \mathrm{C}\right)$

$C_{\mathrm{ZrC}_{2}}=6.54 \times 10^{-6} \mathrm{~mol} / \mathrm{c}$.c

\begin{tabular}{c|c|c|c|c|c}
\hline$\eta(\mathrm{mV})$ & 10 & 15 & 20 & 25 & 30 \\
\hline$i_{0}\left(\mathrm{~mA} / \mathrm{cm}^{2}\right)$ & $1.57_{4}$ & $1.61_{6}$ & $1.67_{5}$ & $1.73_{8}$ & $1.80_{4}$ \\
$k_{f}(\mathrm{~cm} / \mathrm{sec}) \times 10^{3}$ & 1.247 & 1.280 & 1.327 & 1.377 & 1.429 \\
$-2 / \sqrt{\pi} \times$ & 18.0 & 17.0 & 16.1 & 15.0 & 14.3 \\
$\left(k_{f} / \sqrt{D_{0}}+k_{b} / \sqrt{D_{R}}\right)$ & & & & & \\
$k_{f} / \sqrt{D_{0}}$ & 0.22 & 0.22 & 0.23 & 0.24 & 0.25 \\
$k_{b} / \sqrt{D_{R}}$ & 15.7 & 14.9 & 14.0 & 13.1 & 12.4 \\
$\alpha$ & $0.34_{9}$ & $0.34_{9}$ & $0.35_{2}$ & $0.34_{8}$ & $0.34_{9}$ \\
$\alpha^{\prime}$ & $0.58_{2}$ & $0.56_{9}$ & $0.56_{\mathrm{j}}$ & $0.58_{7}$ & $0.56_{7}$ \\
\hline
\end{tabular}

$D_{0}=5.80 \times 10^{-5} \mathrm{~cm}^{2} / \mathrm{sec}$ 
表 $3 \mathrm{NaCl}-\mathrm{KCl}$ (当モル) 融解塩中での $\mathrm{Zr}^{2+}$ の 䢬元反応の速度論的ペシメーター $\left(860^{\circ} \mathrm{C}\right)$ $C_{\mathrm{ZrCl} 2}=6.46 \times 10^{-6} \mathrm{~mol} / \mathrm{c} . \mathrm{c}$

\begin{tabular}{c|c|c|c|c|c}
\hline$\eta(\mathrm{mV})$ & 10 & 15 & 20 & 25 & 30 \\
\hline$i_{0}\left(\mathrm{~mA} / \mathrm{cm}^{2}\right)$ & $1.70_{1}$ & $1.75_{9}$ & $1.83_{0}$ & $1.90_{1}$ & $1.98_{1}$ \\
$k_{f}(\mathrm{~cm} / \mathrm{sec}) \times 10^{3}$ & 1.363 & 1.410 & 1.466 & 1.522 & 1.588 \\
$-2 / \sqrt{\pi} \times$ & 16.4 & 15.4 & 14.6 & 13.7 & 12.8 \\
$\left(k_{f} / \sqrt{D_{0}}+k_{b} / \sqrt{D_{R}}\right)$ & 0.22 & 0.23 & 0.24 & 0.25 & 0.26 \\
$k_{f} / \sqrt{D_{0}}$ & 14.3 & 13.4 & 12.7 & 11.9 & 11.1 \\
$k_{b} / \sqrt{D_{R}}$ & $0.37_{5}$ & $0.37_{6}$ & $0.37_{8}$ & $0.37_{5}$ & $0.38_{2}$ \\
$\alpha$ & $0.59_{2}$ & $0.58_{3}$ & $0.57_{7}$ & $0.58_{5}$ & $0.59_{1}$ \\
$\alpha^{\prime}$ & & & & & \\
\hline
\end{tabular}

$D_{0}=3.85 \times 10^{-5} \mathrm{~cm}^{2} / \mathrm{sec}$

3.2 項にて求めた各過電圧值の $k_{f}$ 㧤よび $k_{b} / \sqrt{D_{R}}$ の対数値を電位に対してプロットすると図 5 に示すよら な直線が得られる.図 5 に招いて $k_{f}$ は良效な遖線を示 すが $k_{b} / \sqrt{\mathrm{D}_{R}}$ の方はやや直線よりはずれる。これは図 4 に㧍けるこう配 $-2 / \sqrt{\pi}\left(k f / \sqrt{D_{0}}+k_{b} / \sqrt{D_{R}}\right)$ 值の 誤差に主として基因する。この值線を各温度における平 衡電位まで外そうすれば，平衡状態における速度定数 $k_{f E e}$ および $k_{b} / \sqrt{D_{R}}$ が求まり, 他方 (7) 式の関係か

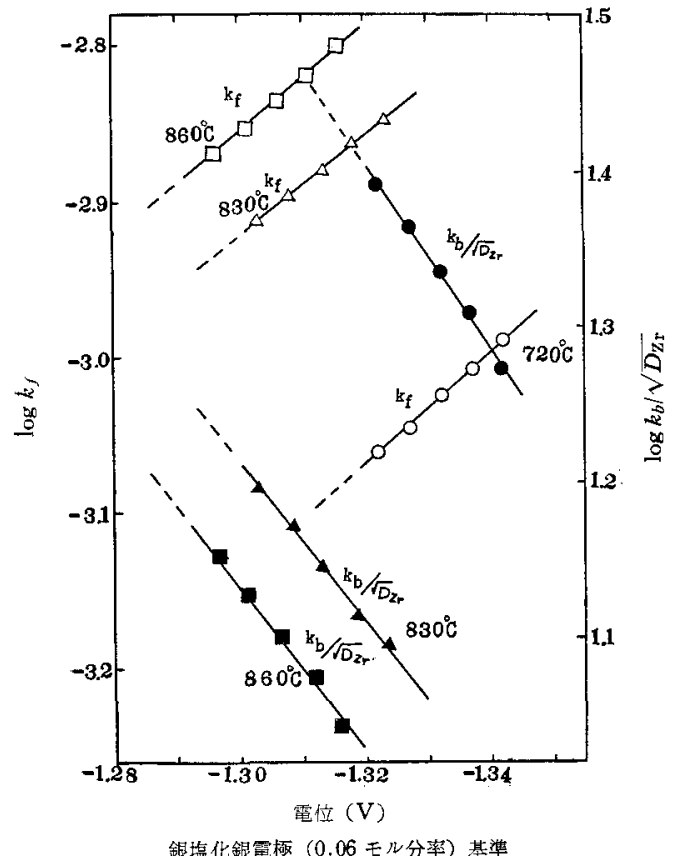

図 $5 \mathrm{NaCl}-\mathrm{KCl}$ (当モル) 中での $\mathrm{Zr}^{2+}+2 e \rightarrow \mathrm{Zr}$ の $\log k_{f}-E, \log k_{b} / \sqrt{D_{\mathrm{z}_{\mathrm{r}}}}-E$ の関係
ら $k_{b E e}$ および $D_{R}$ すなわち $D_{\mathrm{Zr}}$ を求めだ。さらに (8) 式および $k_{f E e}=k_{f}^{0} \exp (-\alpha n F E e / R T)$ の関係よ り $k_{f}{ }^{0}, k_{b}{ }^{0}$ 求めることができる。表 4 に洛温度にお ける平衡電位, $k_{f E e}, k_{b E e}, D_{Z_{\mathrm{r}}}, k_{f}{ }^{0}$ および $k_{b}{ }^{0}$ 值を求 めて示す.

表中 $k_{b}{ }^{0}$ 注実娩值の $\alpha, \alpha^{\prime}$ をそのまま用いて計算した 值 $\left(\alpha+\alpha^{\prime} \neq 1\right), k_{b}{ }^{0 \prime}$ は実験值 $\alpha$ と $\alpha^{\prime}=1-\alpha$ として計 算した值を示す，このようにして $k_{f}^{0}$ および $k_{b}{ }^{0}$ が求ま

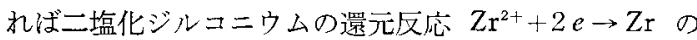
各温度に打ける電位 $E$ の場合の正方向速度定数 $k_{f}$, 逆 方向の速度定数 $k_{b}$ が求まる，その結果を表 5 に示した。

表 $5 \mathrm{NaCl}-\mathrm{KCl}$ (当モル) 融解塩中に括ける $\mathrm{Zr}^{2+}+2 e \rightarrow \mathrm{Zr}$ 庈応の $k_{f}, k_{b}$ 值

\begin{tabular}{c|c|c|c}
\hline$k(\mathrm{~cm} / \mathrm{sec})$ & $k_{f}$ & $k_{b}$ & $k_{b^{\prime}}$ \\
\hline 720 & $\begin{array}{l}2.5 \cdot 10^{-12} \times \\
\exp (-8.18 E)\end{array}$ & $\begin{array}{c}3.4 \cdot 10^{6} \times \\
\exp (13.1 E)\end{array}$ & $\begin{array}{l}4.5 \cdot 10^{8} \times \\
\exp (15.2 E)\end{array}$ \\
\hline \multirow{2}{*}{830} & $\begin{array}{l}3.1 \cdot 10^{-11} \times \\
\exp (-7.36 E)\end{array}$ & $\begin{array}{c}3.0 \cdot 10^{5} \times \\
\exp (12.1 E)\end{array}$ & $\begin{array}{l}1.3 \cdot 10^{7} \times \\
\exp (13.7 E)\end{array}$ \\
\hline 860 & $\begin{array}{l}1.7 \cdot 10^{-11} \times \\
\exp (-7.70 E)\end{array}$ & $\begin{array}{c}2.2 \cdot 10^{5} \times \\
\exp (12.0 E)\end{array}$ & $\begin{array}{l}1.4 \cdot 10^{6} \times \\
\exp (12.8 E)\end{array}$ \\
\hline
\end{tabular}

表中 $k_{b}{ }^{\prime}$ 法表 4 の場合と同様 $\alpha^{\prime}=1-\alpha$ と考えて算出 したものである。

また $(10)$ 式より無限希釈基準の標準電位 $\left(E^{\circ}\right)$ およ び標準速度定数 $\left(k_{s}\right)$ を算出して表 6 に示した。 $E^{0 r}$ 拧 よび $k_{s}{ }^{\prime}$ はいずれも $\alpha^{\prime}=1$ - $\alpha$ として算出した值を示 す. 表中 $E_{i}{ }^{3}$ 湔前報 ${ }^{2} の 二$ 塩化ジルコニウムの平衡電位 の測定結果で比較のためかかげた。

表 6 各温度における二塩化ジルコニウムの標準電位 $\left(E^{0}\right)$ 括よび標準速度定数 $\left(k_{s}\right)$ の值

\begin{tabular}{|c|c|c|c|c|c|}
\hline $\begin{array}{r}E^{0}(\mathrm{~V}) \\
k_{s}(\mathrm{~cm} / \mathrm{sec})\end{array}$ & 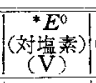 & 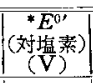 & $\left.\mid \begin{array}{c}{ }^{*} E_{i}{ }^{0} \\
(\text { 対監素) } \\
(\mathrm{V})\end{array}\right)$ & $k_{s}$ & $k_{s^{\prime}}$ \\
\hline 720 & $-2.05_{2}$ & $-2.08_{1}$ & -1.982 & $4.8 \times 10^{-7}$ & $6.0 \times 10^{-3}$ \\
\hline 830 & $-1.99_{3}$ & $-2.02_{3}$ & -1.919 & $6.9 \times 10^{-7}$ & $8.6 \times 10^{-7}$ \\
\hline 860 & $-1.98_{8}$ & $-2.00_{3}$ & -1.901 & $6.8 \times 10^{-7}$ & $7.5 \times 10^{-7}$ \\
\hline$d E / d T\left(\mathrm{~V} /{ }^{\circ} \mathrm{C}\right) \times 10^{4}$ & 4.6 & 5.6 & 5.1 & - & - \\
\hline
\end{tabular}

\section{* 以当机壬無限希积基望}

表 6 を見ると $E_{i}{ }^{0}$ に比べて $E^{0}$ および $E^{0 \prime}$ はいずれ 当高い電位 (負值) 宗している.この点については今 後さらに検討すべき閏題であるが, 浴中に三塩化ジルコ ニウムもしく注四塩化ジルコニウムが微量存在し測定し た電流密度の数值は実際よりも大きく得られ $k_{f}$ 值が大 となり，計算の結果得られた $E^{0}$ 值または $E^{0 \prime}$ 值は大き くなったものと考えられる.なお $\alpha, \alpha^{\prime}$ および $\alpha, 1-\alpha$ 表 $4 \mathrm{NaCl}-\mathrm{KCl}$ (当モル) 融解塩中にょける $\mathrm{Zr}^{2+}+2 e \rightarrow \mathrm{Zr}$ の平衡電位,

$k_{f E_{e}}, k_{b E_{e}}, k_{f}{ }^{0}, k_{3}{ }^{0}$ おるひび $D_{z_{\mathrm{r}}}$ の值

\begin{tabular}{|c|c|c|c|c|c|c|c|c|}
\hline$\left({ }^{\circ} \mathrm{C}\right)^{\text {度 }}$ & 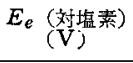 & $C_{0}(モ ル / c . c)$ & $k_{f E e}(\mathrm{~cm} / \mathrm{sec})$ & $k_{b E e}(\mathrm{~cm} / \mathrm{sec})$ & $D_{\mathrm{Zr}}\left(\mathrm{cm}^{2} / \mathrm{sec}\right)$ & $k_{f}{ }^{0}(\mathrm{~cm} / \mathrm{sec})$ & $k_{b}^{0}(\mathrm{~cm} / \mathrm{sec})$ & $k_{b}{ }^{0 \prime}(\mathrm{cm} / \mathrm{sec})$ \\
\hline 720 & -2.392 & $6.81 \times 10^{-6}$ & $7.94 \times 10^{-4}$ & $7.7 \times 10^{-8}$ & $4.6 \times 10^{-18}$ & $2.5 \times 10^{-12}$ & $3.4 \times 10^{6}$ & $4.5 \times 10^{8}$ \\
\hline 830 & -2.365 & $6.54 \times 10^{-6}$ & $1.15 \times 10^{-3}$ & $1.07 \times 10^{-7}$ & $3.6 \times 10^{-17}$ & $3.1 \times 10^{-11}$ & $3.0 \times 10^{5}$ & $1.2 \times 10^{7}$ \\
\hline 860 & -2.356 & $6.46 \times 10^{-6}$ & $1.26 \times 10^{-3}$ & $1.16 \times 10^{-7}$ & $5.2 \times 10^{-17}$ & $1.7 \times 10^{-11}$ & $2.2 \times 10^{5}$ & $1.4 \times 10^{6}$ \\
\hline
\end{tabular}

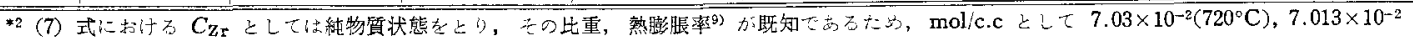
$\left(830^{\circ} \mathrm{C}\right), 7.010 \times 10^{-2}\left(860^{\circ} \mathrm{C}\right)$ t用いた。 


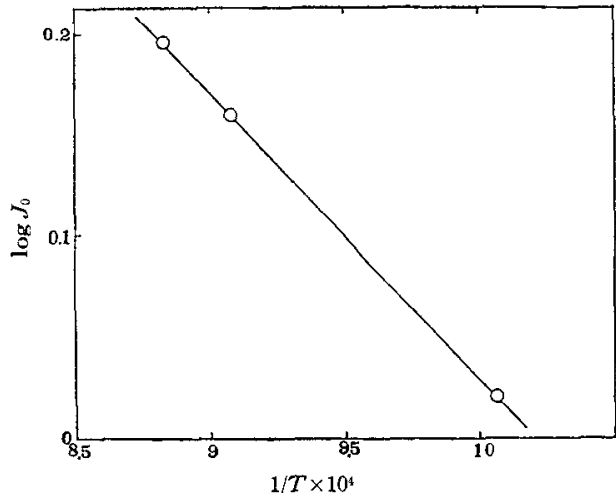

図 $6 \log J_{0}-1 / T$ の関倸

を用いて得られた $E^{0} ， E^{0 \prime}$ 值については，精度的に考え ていずれが正しいかは簡単には論じられなく、今後さら に検討する.

\section{4 活性化エネルギー}

表 1〜3に示した各過電圧值に拉ける電流密度を $\eta \rightarrow$ 0 に外々うして得られる電流密度 $\left(J_{0}=n F k_{f E e} C_{0}\right)$ すな わち交換電流密度を求め $1 / T$ に対してプロットすれば 図6のごとくなる、いまアレニウスの式より活性化エネ ルギーを計算すると $6.6 \mathrm{kcal} / \mathrm{mol}$ となり Laitinen ら ${ }^{10)}$ が $\mathrm{Cd}^{2+}, \mathrm{Zn}^{2+}$ 抢よび $\mathrm{V}^{3+}$ イオンの還元反応について $450^{\circ} \mathrm{C} \mathrm{KCl}-\mathrm{LiCl}$ (共晶) 融解塩にてそれぞれ $3 \pm 1 \mathrm{kcal}$ ， $\mathrm{mol}, 2.8 \pm 0.4 \mathrm{kcal} / \mathrm{mol}$ なる数值定報告している.また われわれが $\mathrm{AgCl}-\mathrm{KCl}\left(70: 30\right.$ モル) 融解塩中で $370^{\circ} \mathrm{C}$ $\sim 550^{\circ} \mathrm{C}$ にて銀の析出溶出過電圧測定 ${ }^{11}$ の結果より銀の 活性化エネルギーは $1.95 \pm 0.03 \mathrm{kcal} / \mathrm{mol}$ であった.

$\mathrm{Zr}^{2+}$ イオンの場合はやや大きい数值を示すことが明ら かになった。

3.5 析出金属ジルコニウムの搪散係数

析出金属ジルコニ゙ウムの搪散你数值仕 3.3 䐜の表 4 に

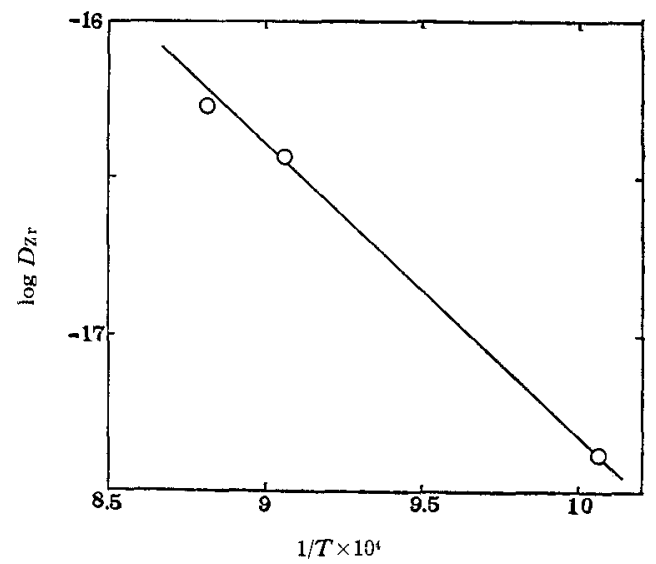

図 $7 \log D_{z_{r}}-1 / T$ の関係
示した、いま $\log D_{\mathrm{Zr}_{\mathbf{r}}} 1 / T$ の関係をプロットすれば図 7 に示すごとく大略值線を示す.このこら配より拡散の 活性化エネルギーおよび頻度因子を求めると，それぞれ $42.6 \pm 2 \mathrm{kcal} /$ モル，10-8 $\mathrm{cm}^{2} / \mathrm{sec}$ となる。すなわち本実 験において析出金属ジルコニウムの拉散係数は，

$$
D_{\mathrm{Zr}}=10^{-8} \cdot \exp (-42,600 \pm 200 / R T)
$$

で示される.この搪散係数值はタングステン電極上におう ける表面拡散，粒界抬散あるいは粒內拡散を示している か，または浴塩中への搪散であるか，その拡散のモデル は明確でない，金属ジルコニウムの自己拡散係数 ${ }^{12\}, 13\rangle}$ 值とも一致せず,この問題についてはさらに今後の研究 とする.

\section{4 総括}

（1） $\mathrm{NaCl}-\mathrm{KCl}$ (当モル) 融解塩中の $\mathrm{Zr}^{2+}$ イオン の還元反応を研究するため, 定電流法によって過電圧の 小さい範囲において過電圧時間の関係を二塩化ジルコニ ウム $4.33 \times 10^{-4}$ モル分率, $720^{\circ} \mathrm{C}, 830^{\circ} \mathrm{C}$, 扎よび $860^{\circ} \mathrm{C}$ において測定した.

(2) $i_{0} t^{1 / 2}-i_{0}$ の関係は適当な電流密度過電圧值にお いて直線を示し $i_{0} t^{1 / 2} \rightarrow 0$ に外之うして得た電荷移動過

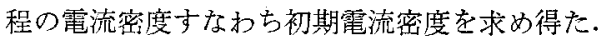

(3) 初期電流密度值㧍よび平衡電位の測定值より, $\mathrm{Zr}^{2+}$ イオンの僄元の動力学的パラメーターすなわら速度 定数 $\left(k_{f}, k_{b}, k_{s}\right)$, 遷移俰数 $\left(\alpha, \alpha^{\prime}\right)$ おるざ標準電位 $\left(E^{0}\right)$ 求的た。この場合 $\alpha+\alpha^{\prime} \neq 1$ であった。

(4) 交換電流密度の温度依存性より求めたこの反応 の活性化エネルギーは $6.6 \mathrm{kcal} / \mathrm{mol}$ であった。

（5）析出金属ジルコニウムの搪散係数值として， $D_{Z_{\mathbf{r}}}=10^{-8} \cdot \exp \{(-42,600 \pm 2,000) / R T\}$ なる結果を得た。

(昭 41-12-28 受理)

\section{文献}

1）坂倉富良，本誌 34，780 (1966).

2）坂倉富良，桐原朝夫，本誌 35，302 (1967).

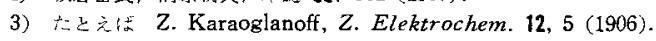

4) P. Delahay, "New Instrumental Methods in Electrochemistry" (1954). Interscienc Publisher. London.

5) J. O'M. Bockris, et. al., Can. J. Chem. 37, 190 (1959).

6) P. Delahay, T. Berzins, J. Am. Chem. Soc. 17, 6448 (1955).

7) Ukshe E.A., N.G. Bukum, D.I. Leikis, Dokl. Akad. Nauk SSSR. 135, 1173 (1960).

8）桐原朝夫, 坂会富良, 日本金属学会講演概要 55,159 (1965).

9) Benjamin Lustman and Frank Kerze, jr., "The Metallurgy of Zirconium" (1955), McGraw-Hill, New York.

10) H.A. Laitinen, R.P. Tischer, D.K. Roe, J. Electrochem. Soc. 107, 546 (1960).

11) 桐原朝夫, 圾倉富良, 永田興三, 溶融塩 8, 90 (1965).

12) P.L. Gruzin, V.S. Emelyanov, G.G. Ryabova, G.B. Fedorov, Proc. UN Inter. Conf. Peaceful Uses At. Energy 2 nd Geneva, 19, 187 (1958).

13) P. Flubacher, E.I.R. Bericht Nr. 49, May (1963). 